Iwona Kowal

Uniwersytet Jagielloński

\title{
DYNAMIKA I STRUKTURA GRUPY W KLASIE JĘZYKOWEJ
}

\section{Group dynamics and group structure in the language classroom}

\begin{abstract}
The present paper describes various psycho-social phenomena that occur in groups, in particular in the language classroom. Each group passes through five developmental stages called forming, storming, norming, performing and adjourning. During these phases learners' behavior and attitudes change, which often leads to conflicts between the teacher and the students. The structure of the group develops in parallel with its dynamics. Students adopt several roles in the group, such as, for example, leader, expert or outsider.
\end{abstract}

Nauka języka obcego najczęściej odbywa się grupach. Zajęcia indywidualne nauczyciel - uczeń mogą stanowić uzupełnienie nauki w środowisku klasy lekcyjnej. Jedyną formą są one najczęściej w przypadku osób dorosłych, które zakończyły już edukację szkolną czy akademicką. W ostatnim czasie wzrosło zainteresowanie badaczy złożonością czynników wpływających na nabywanie języka obcego i wynikającą z niej niemożnością jednoznacznego przewidzenia tempa nauki czy możliwości osiągnięcia określonego poziomu kompetencji językowych. Wśród językowych, psychologicznych i społecznych zmiennych warunkujących naukę języka wymienia się najczęściej podobieństwo między językiem wyjściowym (ojczystym, pierwszym językiem obcym) a językiem aktualnie nabywanym, stopień świadomości metajęzykowej ucznia, jego motywację, strategie uczenia się, pochodzenie społeczne, inteligencję czy uzdolnienia językowe.

Mimo świadomości występowania tak wielu czynników nauczyciel języka obcego niejednokrotnie zostaje zaskakiwany sytuacjami, gdy dotychczas chętnie współpracujący uczniowie nagle przestają przygotowywać się do zajęć, gdy mimo niezmienionych warunków nauki i metod nauczania 
klasa wydaje się nie rozumieć przekazywanego materiału, gdy uczniowie zaczynają kwestionować polecenia nauczyciela czy wręcz wyraźnie okazywać mu swoje niezadowolenie. Niejeden nauczyciel języka obcego z pewnością zadawał sobie pytanie, dlaczego podczas pracy w parach czy podgrupach niektóre osoby wykonują dane zadanie z zaangażowaniem i w wyznaczonym czasie, inne kończą już po minucie i siedzą bezczynnie, nie podtrzymując kontaktu z innymi osobami z podgrupy. Równie zastanawiające są z pewnością sytuacje, gdy nauczyciele podczas rozmowy na temat danej klasy/grupy uczniów mają odmienne zdanie: według jednego z nich uczniowie byli uprzejmi, chętnie wykonywali ćwiczenia, byli w stosunku do siebie życzliwi i chętni do pomocy. Zdaniem innego nauczyciela uczniowie niechętnie współpracowali ze sobą, byli we wzajemnej rywalizacji, nieuprzejmi, nie wykonywali poleceń prowadzącego. Można by odnieść wrażenie, że rozmawiają o dwóch różnych klasach. Takie zjawiska stanowią namacalny przykład zmian związanych z dynamiką grupy jako całości, zmian zachodzących w jej strukturze w czasie i wpływających nie tylko na wzajemne relacje między uczniami, czy między uczniami a nauczycielem, lecz także na możliwość prowadzenia dyskursu językowego i sam proces nauki języka obcego.

\section{Klasa językowa jako grupa}

W socjologii i psychologii społecznej wyróżnia sie trzy typy zbiorowisk ludzkich: tłum, grupę i zespół. Tłumem określa się zbiór osób niezwiązanych ze sobą, znajdujących sie $w$ danym miejscu i o danej porze. Będą nim więc klienci w sklepie czy pasażerowie autobusu. Zespół to wysoko zorganizowany zbiór osób, które zebrały się w określonym celu i gdzie każda z osób ma przypisane konkretne zadania do realizacji celu. Za zespoły uznać można lekarzy i personel pomocniczy podczas operacji czy drużynę piłkarską. Grupa natomiast to zbiór osób, które zebrały się w określonym celu i współdziałają ze sobą do jego osiągnięcia. Grupą w takim rozumieniu będzie klasa szkolna, grupa turystów wyruszająca na wspólną wycieczkę czy grupa terapeutyczna.

Grupa charakteryzuje się określonymi cechami:

- w jej skład wchodzą co najmniej dwie osoby,

- jej członkowie czują się związani ze sobą i mają świadomość przynależności do grupy,

- $\quad$ występuje pewna ilość wyraźnie określonych bądź niepisanych norm i zasad, służących osiągnięciu zamierzonego celu,

- $\quad$ w trakcie jej trwania grupa wytwarza charakterystyczną dla niej kulturę oraz tożsamość, 
- podstawowe znaczenie dla grupy mają relacje interpersonalne oraz wzajemne powiązania między uczestnikami,

- aby praca w grupie była skuteczna, musi istnieć równowaga między celem grupy a procesem współpracy członków grupy (Brid, 2008).

Zjawiskami toczącymi się grupach zajmowali się badacze już na początku XX wieku, przy czym punkt ciężkości spoczywał na aspekcie terapeutycznym. Burrow (1928) jako pierwszy użył pojęcia grupa jako całość (group as a whole) oraz rozpoznał, że zjawiska dotyczące grup funkcjonują niezależnie od zachowań i działań poszczególnych jej członków. We wczesnym okresie badań z zakresu psychologii społecznej na różnice w zachowaniach grupy $\mathrm{i}$ jednostek zwrócili także uwagę McDougall (1921) i Allport (1924). Moreno, twórca psychodramy i socjometrii, wskazywał na zależność między istnieniem i funkcjonowaniem grupy a zachowaniem się jej członków we wzajemnej interakcji. Moreno podkreślał także ważność spotkania na kształtowanie się osobowości człowieka i jego relacji z innymi osobami w grupie (Moreno, 1953). Według Durkina (1980) grupa to żywy system zmieniających się podmiotów, informacji i energii.

Klasa szkolna czy klasa/grupa językowa spełnia więc wszystkie kryteria grupy z definicyjnego punktu widzenia. Ma ona wspólny cel: naukę języka obcego. W klasie językowej jest od około dziesięciu do około dwudziestu osób. Stanowi to zatem tzw. „grupę średnią" pod względem wielkości (grupy małe liczą poniżej dziesięciu członków, średnie - od dziesięciu do 20-25 osób, natomiast duże powyżej dwudziestu osób). Czas trwania grupy językowej uzależniony jest od instytucji, w której jest tworzona. W przypadku krótkich kursów może być to okres kilkutygodniowy lub kilkumiesięczny, w szkołach na poziomie podstawowym, ponadpodstawowym i średnim grupa językowa istnieje trzy do sześciu lat, podobnie na poziomie szkolnictwa wyższego (dwa, trzy lub pięć lat). Klasy językowe, w odróżnieniu od np. grup terapeutycznych mają zazwyczaj charakter grup zamkniętych, tzn. skład jej członków nie ulega radykalnym zmianom. Mogą zdarzyć się odejścia pojedynczych osób lub dołączenie nowych uczniów. Większość uczestników pozostaje jednak w grupie do końca jej istnienia. Nauczyciel z zasady prowadzi uczniów przez cały czas. Zdarzają się jednak przypadki zmiany uczącego po określonym etapie nauki (semestr, rok) bądź równoległe prowadzenie zajęć językowych przez kilku nauczycieli (np. na filologiach). Przez ten okres tworzą i rozwijają się relacje między członkami, kształtują określone wzorce zachowań, wspólne powiedzenia, normy (zarówno te, narzucane przez samą instytucję przy prowadzącego jak i niepisane - np. zajmowanie miejsc w sali lekcyjnej). 


\section{Dynamika grupy}

Przy porównaniu zjawisk zachodzących w różnych grupach (dzieci, młodzieży, dorosłych, grup złożonych z samych mężczyzn bądź z samych kobiet) badacze zauważyli pojawiającą się zmienność zachowań członków w trakcie uczestnictwa w grupie. Lewin zaproponował w związku z tym nowe spojrzenie na ów twór społeczny, odchodząc od opisu grupy jako zbioru osób charakteryzujących się pewnym podobieństwem (płci, pochodzenia, zawodu czy postawy), lecz podkreślając dynamiczną zależność między członkami grupy/podgrupy oraz wpływ różnych procesów na zmiany ich zachowań (Lewin, 1939, 1992).

Lewin oraz Moreno uważani są za twórców dynamiki grupy jako jednego z obszarów zainteresowań psychologii społecznej. W trakcie rozwoju tej dziedziny opracowano specyficzne stopnie rozwojowe grupy, zwane fazami i charakteryzujące się określonymi cechami. Zauważono, że każda grupa przechodzi przez te same etapy w swoim rozwoju. Najczęściej przytaczanym modelem dynamiki grupy jest model Tuckmana (1965), początkowo składający się z czterech faz, a następnie, w wyniku dalszych obserwacji i badań, rozszerzony do pięciu faz (Tuckman i Jensen, 1977). W kontekstach pracy z zespołami model ten nazywany też bywa „zegarem rozwoju zespołów” (Voigt, 1993, Gellert i Nowak, 2007). Tuckman dokonał syntezy wyników badań przeprowadzonych na ponad pięćdziesięciu grupach różnego rodzaju (grupach terapeutycznych, laboratoryjnych, treningowych i tzw. grupach naturalnych) i na podstawie zestawienia wspólnych zachowań zaobserwowanych przez badaczy zaproponował używany do dziś model faz dynamiki grupy.

Fazy rozwoju grupy:

1. Faza orientacji.

2. Faza konfliktu.

3. Faza zaufania.

4. Faza konstruktywnej współpracy.

5. Faza rozstania.

\subsection{Faza orientacji}

Pierwotnie ten stopień rozwoju nazywany był procesem formowania się grupy (forming). Obecnie częściej pojawia się termin „faza orientacji”, dzięki czemu podkreślany jest element rozeznawania się w nowej sytuacji bycia w grupie, a nie tylko fakt tworzenia się grupy. Podstawowymi cechami wyróżniającymi tę fazę jest testowanie i zależność. Pojęcie „testowanie” odnosi się do sprawdzania, jakie zachowania mogą być zaakceptowane zarówno przez prowadzącego (trenera, nauczyciela, terapeutę) oraz przez pozostałych 
członków grupy. Dzięki temu uczestnicy próbują zidentyfikować powiązania na poziomie interpersonalnym jak i na poziomie nadrzędnego celu grupy. $Z$ testowaniem związana jest zależność w stosunku do prowadzącego, innych osób z grupy bądź istniejących standardów czy narzuconej struktury.

Jak Gellert i Nowak (2007) podkreślają, fazę tę charakteryzuje duża niepewność. Członkowie grupy używają określonych, rytualnych sposobów komunikowania się. Widoczne jest zaciekawienie tym, co nastąpi oraz gotowość do dostosowania się do norm i zasad, związana głównie z zależnością, charakteryzującą tę fazę. Grupa jako całość jeszcze nie istnieje. Uczestnicy potrzebują jasnych, określonych struktur, żeby poczuć się pewnie i poznać stawiane im oczekiwania. Zadaniem prowadzącego jest przede wszystkim przedstawienie ogólnych warunków pracy w grupie (struktury czasowej, stawianych celów, wymagań instytucjonalnych oraz indywidualnych). Poza tym powinien on swoją postawą wzbudzić zaufanie uczestników zarówno, co do jego kompetencji merytorycznych jak i osobowościowych (zadbanie o dobrą atmosferę pracy, ochrona przed wyśmianiem czy deprecjonowaniem). Celem aktywności prowadzącego na tym etapie pracy z grupą jest umożliwienie poczucia się w grupie, zmniejszenie niepewności i lęku przed oceną i stworzenie dobrych warunków do wspólnej pracy.

\subsection{Faza konfliktu}

Wyjątkowość fazy konfliktu dostrzec można choćby w terminach ją określających. W literaturze przedmiotu poza powszechnie przyjętą nazwą „faza konfliktu” pojawiają się sformułowania "faza konfliktu i zajęcia pozycji” (Gellert i Nowak, 2007), „faza zmian” (Ehrman i Dörney, 1998), „okres krytyczny” (Parker, 1958), „okres walki i ucieczki” (Bion, 1961). Badacze podkreślają wyraźną w tym czasie polaryzację w grupie (Barron i Krulee, 1948, Bradford, 1964).

Faza konfliktu często porównywana jest do okresu dojrzewania człowieka. Podobnie jak dziecko na tym etapie swojego rozwoju, także i grupa jako całość zaczyna konfrontować się z autorytetem - nauczycielem, trenerem czy terapeutą. Uczestnicy zaczynają sprawdzać, jak prowadzący przestrzega wprowadzonych przez siebie zasad, czyniąc to poprzez próby przekraczania ich. Członkowie grupy stają się szczególnie wyczuleni na błędy prowadzącego, stawiają pytania dotyczące metody pracy, często kwestionując jej skuteczność. Wyrażają otwartą niechęć do wykonywania poleceń. Widoczne są także konflikty między poszczególnymi uczestnikami. W trakcie fazy konfliktu zaczynają wyodrębniać się podgrupy i każdy stara się zająć jak najlepszą dla siebie pozycję w grupie - rolę przywódcy, eksperta czy lubianej osoby. W związku z tworzeniem się mniejszych grup dochodzić może do ich 
wzajemnej rywalizacji. Uczestnicy wybierają jak najlepszą strategię zarówno w celu przetrwania tego okresu (co odbywa się na poziomie podświadomym) jak i dla uzyskania odpowiedniego statusu w grupie na przyszłość.

Dynamika grupy w tym okresie może negatywnie wpłynąć na pracę merytoryczną i realizowanie wytyczonych celów. Dla prowadzącego ważne jest, aby uświadomił sobie, że opór ze strony grupy, czy jej niechęć do wykonywania prac wynika ze specyfiki fazy, w jakiej aktualnie grupa znajduje się $\mathrm{i}$ zazwyczaj nie jest bezpośrednio związany z osobą prowadzącego. W tym okresie szczególne znaczenie mają kompetencje społeczne nauczyciela czy trenera a także jego umiejętności psychologiczne, takie jak empatia czy dojrzałość emocjonalna. Konieczne jest także częste odwoływanie się do ustalonych zasad i używanie racjonalnych argumentów.

\subsection{Faza zaufania}

W tym okresie grupa wyraźnie zaczyna funkcjonować jako całość oraz postrzegać siebie jako odrębny byt o wyraźnej tożsamości. Dzięki temu rośnie solidarność i integracja. Grupa ma już za sobą okres ścierania się, a wyodrębnione w fazie konfliktu podgrupy nie muszą już dążyć do prawa bytu. W wyniku świadomości bycia grupą mogą powstawać charakterystyczne tylko dla niej rytuały czy powiedzenia. Jak podkreśla Tuckman (1965) w okresie tym rośnie spójność grupy i jej otwarcie się na poszczególnych uczestników. Zmniejsza się także lęk przed oceną ze strony grupy, co skutkuje bardziej swobodnym wypowiadaniem własnych myśli na forum całej grupy.

Gellert i Nowak (2007) opisują rolę prowadzącego jako osoby dającej przestrzeń uczestnikom i jednocześnie podkreślającej ich własne kompetencje. Ma on zachęcać do pracy i być bardziej moderatorem niż wychowawcą. Może się zdarzyć, że prowadzącego wręcz uwiedzie dobra atmosfera panująca w grupie. Ważne jest wtedy, aby nie zapomnieć o swojej roli i nie dopuścić do zatarcia granicy między prowadzącym a członkami grupy.

\subsection{Faza konstruktywnej współpracy}

Faza konstruktywnej współpracy jest niejako naturalną konsekwencją poprzednich etapów. Po okresie walki i stworzenia zaufania członkowie grupy nabyli umiejętności współpracy z innymi osobami. Uczestnicy respektują ustalone normy, konkurencja między nimi nie jest już na pierwszym planie, dzięki czemu możliwa jest skuteczne współdziałanie na przykład w tworzeniu projektów czy realizacji wytyczonych zadań. Grupa postrzegana jest jako dojrzały 
twór, mogący samodzielnie proponować określone działania. Rośnie także kultura uczestników, którzy stają się bardziej autentyczni w wyrażaniu krytyki.

Zadaniem prowadzącego jest umiejętne kierowanie działaniami grupy. W tym okresie widoczna jest chęć uczestników do wykonywania prac wymagających wspólnego działania, stąd też bardzo często w tym okresie realizowane są projekty tematyczne czy jednorazowe zadania wymagające pracy kilku uczestników na raz. Gellert i Nowak (2007) zwracają uwagę na ryzyko związane z przecenianiem swoich umiejętności, co najczęściej wyraża się wyraźnym odcinaniem się od innych grup, przy podkreślenie swojej wyjątkowości czy niezawodności.

\subsection{Faza rozstania}

Przy pierwszym rozróżnieniu i nazwaniu faz rozwoju grupy (Tuckman, 1965) faza rozstania nie była wyodrębniona. Jak wspomniano powyżej, uwzględniono ją w opisie dynamiki grupy kilkanaście lat później, w wyniku dalszych obserwacji funkcjonowania grup (Tuckman i Jensen, 1977). Faza rozstania może uwidocznić się w dwojaki sposób. W przypadku grup, których czas trwania jest ustalony przez instytucję (szkołę, placówkę terapeutyczną czy szkoleniową), uczestnicy wiedzą, kiedy kończy się kontrakt zawarty na realizację wytyczonego celu i samoistnie dokonują wewnętrznego rozstania poprzez zmianę punktu ciężkości swoich zainteresowań na życie poza grupą. W grupach, których nie ustalono wyraźnie ich czasu trwania, a jedynie określono cel realizacji (np. wspólna wycieczka), fazę rozstania można rozpoznać po bezproduktywności dalszych działań czy po skupianiu się na tym, co grupa wspólnie już przeszła. Może się także zdarzyć, że grupa rozpadnie się w wyniku odejścia zbyt dużej ilości osób, a dołączenie do niej nowych uczestników spowoduje utworzenie nowej grupy i rozpoczęcie procesu formowania.

Charakterystyczne dla fazy rozstania jest przejście od identyfikowania się z grupą jako całością do postrzegania siebie jako odrębnej osoby. Często może się zdarzyć, że uczestnicy wypierają jednak fakt zakończenia się grupy, co przejawia się w działaniach służących utrzymaniu grupy jako całości - na przykład w formie regularnych spotkań poza dotychczasowym miejscem pracy grupy.

Prowadzący powinien uświadamiać grupie, czego dokonała, aby uczestnicy poznali wartość wspólnej pracy. Jednocześnie zaleca się, aby zaproponował określoną formę zakończenia grupy, co z jednej strony może uruchomić świadome wspólne przygotowanie się na funkcjonowanie poza grupą, z drugiej strony uniknie się wypierania faktu zakończenia czasu trwania grupy. 


\section{Dynamika grupy w klasie językowej}

Klasa językowa, jak każda grupa przechodzi poszczególne fazy jej rozwoju. Należy przy tym zwrócić uwagę, że nie ma ustalonego czasu trwania każdej z faz oraz że niektóre fazy (np. faza konfliktu) mogą w ogóle nie wystąpić albo trwać bardzo krótko (na przykład przez jedną lekcję). Może się także zdarzyć, że grupa powróci do wcześniejszej fazy. Często dzieje się tak w przypadku dołączenia kilku nowych osób bądź odejścia jednej, ale bardzo ważnej osoby w grupie. Wówczas, niezależnie od tego, w której fazie klasa aktualnie się znajdowała, może ona ponownie rozpocząć proces formowania się. Możliwe są także sytuacje powrotu do fazy konfliktu, gdy nagle zmienią się warunki pracy (poprzez zmianę miejsca czy wykładowcy). Każdy nauczyciel, nie tylko języka obcego, powinien mieć świadomość występowania dynamiki grupy i starać się rozpoznawać poszczególne jej fazy.

W nauczaniu języka obcego istotny jest nie tylko dobór materiałów, lecz także odpowiednich metod służących przekazaniu go. Metody nauczania nie mogą jednak być sztywno stosowane bez względu na klasę, z jaką się współpracuje. Należy mieć także świadomość, że metody te nie są uniwersalne, tzn. powodzenie w zastosowaniu ich w danej klasie nie oznacza, że odniosą one taki sam skutek $w$ innej klasie, czy nawet $w$ tej samej grupie uczniów, ale znajdującej się na innym etapie rozwoju. Dlatego przed zastosowaniem danego zadania czy danej metody nauczania tak ważna jest refleksja nauczyciela na temat fazy rozwojowej, w jakiej klasa aktualnie się znajduje, aby móc ocenić, czy zaplanowane działanie będzie mogło być wykonane przez uczniów. Nie chodzi tu o stopień trudności, lecz przede wszystkim o ewentualną interakcję uczniów w trakcie jego wykonywania i co za tym idzie - skuteczność interwencji nauczyciela.

\subsection{Działania nauczyciela $w$ fazie orientacji}

Niezależnie od tego, czy nauczyciel rozpoczyna pracę z klasą znającą już nauczany język na określonym poziomie czy klasą początkującą, uczniowie w równym stopniu będą się czuć niepewnie. W przypadku grup co najmniej średnio zaawansowanych niepewność ta może być tym większa, im mniejsza jest wiedza uczniów na temat poziomu umiejętności kolegów z grupy. Helbig (2001) zwraca uwagę na rolę nauczyciela jako aktywnego moderatora głównie $w$ tej pierwszej fazie pracy grupy, gdy jednym z podstawowych jego zadań jest przezwyciężenie lęku uczniów przed nauką oraz konkurencją miedzy uczniami.

W celu ułatwienia uczniom bezpiecznego poczucia się w klasie nauczyciel może stosować różne ćwiczenia służące ich wzajemnemu poznaniu 
się. Dobrze jest zastosować ćwiczenia socjometryczne, polegające na zajmowaniu pozycji w zależności od ustanowionego kryterium (np. miejsce urodzenia, zainteresowania, profil wcześniej ukończonej szkoły, długość i miejsce nauki języka obcego, wcześniejszy stopień znajomości innych osób z klasy). Dzięki temu uczniowie pokazują się w różnych konstelacjach i nie czują się osamotnieni, widząc w klasie np. osoby z tego samego osiedla czy lubiące ten sam zespół muzyczny. Jednocześnie nauczyciel ma możliwość zauważenia już na początku, czy istnieją grupy osób znających się z innych okoliczności (wspólna szkoła, wspólny kurs językowy), co może skutkować wczesnym zawiązaniem się podgrup silnie wpływających na procesy dynamiki grupy. Decyzja, czy do takiego rodzaju ćwiczeń zastosuje się język ojczysty, czy język obcy, zależy od nauczyciela i wybranej przez niego metody nauczania. Decydując się na użycie języka obcego należy jednak liczyć się z uaktywnieniem się lęku u osób niepewnych, dla których dużym wyzwaniem jest odnalezienie się w każdej nowej sytuacji.

Stworzeniu poczucia bezpieczeństwa w grupie służyć będzie także wyraźne poinformowanie uczniów o zasadach - nie tylko o sposobie oceniania czy trybie przeprowadzania prac kontrolnych, ale także o normach ułatwiających wzajemna współpracę, np. niespożywanie napojów i posiłków podczas lekcji, nieużywanie telefonów komórkowych czy punktualne przychodzenie na zajęcia. Niektóre z tych zasad mogą wydawać się oczywiste, jeśli jednak nie zostaną one bezpośrednio podane na początku pracy, mogą w fazie konfliktu stanowić temat dyskusji i niepotrzebnych spięć.

\subsection{Działania nauczyciela $w$ fazie konfliktu}

Faza konfliktu związana jest często z dużymi emocjami zarówno ze strony uczniów jak i nauczyciela. Emocje mogą wynikać z pozycjonowania się uczniów wewnątrz grupy jak i z okoliczności natury formalnej, jak na przykład z powodu zbliżającego się terminu ważnego sprawdzianu czy egzaminu. Nauczyciel powinien być przygotowany na to, że będzie prowokowany przez uczniów. $W$ ten sposób silniejsi członkowie klasy będą sprawdzać zarówno jego kompetencje merytoryczne jak i siłę autorytetu. Mogą manifestować niechęć wobec określonych poleceń (np. pracy w parach czy pisania wypracowań), uznając je za nudne bądź zbyt pracochłonne. Istotne $w$ tej fazie jest, aby nie podchodzić osobiście do ogólnie stawianych zarzutów oraz nie wycofywać się z przeprowadzenia planowanych ćwiczeń pod wpływem niezadowolenia uczniów.

Przy pracy w parach czy podgrupach dobrze jest zaproponować taki wybór partnerów, aby uniknąć wspólnej pracy w jednym zespole osób będących w aktualnym konflikcie (np. przywódców dwóch podgrup), gdyż prawdopodobieństwo 
ich owocnej współpracy będzie w tym okresie równe zeru. Dyskusje na określone tematy na forum grupy mogą przerodzić się w kłótnie między uczniami, a w przypadku klas językowych na poziomie zaawansowanym zauważyć można częste odchodzenie od używania (zaleconego) języka obcego na rzecz języka ojczystego. Przygotowywane przez uczniów prezentacje mogą spotkać się z wyraźnie okazywanym brakiem zainteresowania ze strony pozostałych członków klasy. Działania nauczyciela w tej fazie mogą skupiać się na ćwiczeniach niewymagających bezpośredniej konfrontacji - stąd może być mniej dyskusji na tematy społeczne a więcej $\mathrm{np}$. ćwiczeń gramatycznych czy prac indywidualnych. Celem tego nie jest unikanie ewentualnej konfrontacji, lecz nieprzenoszenie jej na czynności związane z doskonaleniem kompetencji językowych.

\subsection{Działania nauczyciela $w$ fazie zaufania}

Gdy klasa znajduje się w fazie zaufania, jest otwarta na nauczyciela i na uczniów. Jest to odpowiedni moment, żeby umożliwić zaistnienie szczególnie bardziej nieśmiałym czy słabszym językowo uczniom, gdyż ryzyko ich wyśmiania przez resztę klasy jest znacznie mniejsze. W tym okresie rozwoju klasa może przyjąć praktycznie wszystkie ćwiczenia, zarówno wymagające występowania na forum całej klasy jak i te, związane z pracą indywidualną czy w parach. W zależności od poziomu zaawansowania można zlecać uczniom przygotowanie prezentacji $\mathrm{w}$ języku obcym czy np. przedstawianie na głos informacji prasowych.

W fazie zaufania klasa najczęściej czuje się jednością i może zachęcać nauczyciela do wspólnego udziału w działaniach pozalekcyjnych, np. wspólnego wyjścia do kawiarni. Jest to z jednej strony informacja dla nauczyciela, że jest przez uczniów akceptowany i lubiany, z drugiej jednak strony istnieje zagrożenie zatarcia się granic między rolami, co w konsekwencji może doprowadzić na przykład do powrotu do fazy konfliktu bądź do wykorzystywania quasi prywatnych relacji do celów służbowych (np. zwolnienie z zapowiedzianego sprawdzianu).

\subsection{Działania nauczyciela w fazie wzajemnej współpracy}

W dojrzałym stadium grupy, jakim jest faza wzajemnej współpracy, od nauczyciela nie wymaga się wyjątkowej aktywności. Jego zadaniem jest dalsze prawidłowe wykonywanie założonych działań, przy czym można oddać większą odpowiedzialność uczniom. Nie oznacza to jednocześnie rezygnacji z tej części odpowiedzialności, która zawsze spoczywa na nauczycielu, czyli realizacji programu nauczania i uczenia postawy etycznej.

Nauczyciel nie musi jednak być już dyrektywny przy wyznaczaniu np. osób do pracy w parach czy podgrupach bądź przy określaniu minimalnej ilości 
stron wypracowania. $W$ tej fazie grupy uczniowie z powodzeniem mogą wykonywać projekty wymagające zaangażowania i współpracy kilku osób. Umieją sami dobrać się w zespoły i przydzielać sobie zadania do wykonania. Angażują się w działania wykraczające poza klasę, np. prezentacje na temat języka i kultury innych krajów na forum szkoły czy organizacja konferencji studenckich.

Mimo dużej niezależności uczniowie potrzebują jednak moderatora w postaci nauczyciela, który jednocześnie pełni ważną funkcję doradcy i eksperta przy przygotowywaniu i prezentacji projektów. Jak zauważają Gellert i Nowak (2007) niektórym nauczycielom owo delegowanie zadań i przejęcie funkcji moderatora może przychodzić z trudem, z uwagi na silne przywiązanie emocjonalne do klasy bądź z nieumiejętność wycofania się.

\subsection{Działania nauczyciela $w$ fazie rozstania}

Faza rozstania jest bez wątpienia okresem, który pozwala na przejście z rzeczywistości bycia częścią klasy do rzeczywistości funkcjonowania jako niezależna osoba (były uczeń czy były nauczyciel danej klasy). Jeśli klasa jest zżyta i bardzo wysoko ceni umiejętności nauczyciela, niechętnie dąży do zakończenia kursu, bądź wręcz udaje, że nauka języka nadal będzie trwała po krótkiej przerwie. Jednocześnie wielu uczniów dostrzega już perspektywy zastosowania uzyskanej wiedzy w innym środowisku.

Celem nauczyciela jest uzmysłowienie uczniom, czego się nauczyli. Można to zrobić w formie wypunktowania konkretnych umiejętności językowych, jakie każdy z uczniów zdobył w trakcie nauki, bądź zwrócenie uwagi na jedną szczególną kompetencję, jaką dany uczeń posiada. W przypadku towarzyszenia danej klasie językowej przez dłuższy okres czasu (np. kilka lat) można przekazać uczniom w formie pamiątki ich prace pisemne, jakie wykonali na przestrzeni tych kilku lat, dzięki czemu będą mogli sami porównać wzrost swoich umiejętności językowych.

Nie bez znaczenia jest także zastosowanie określonych rytuałów pożegnania. Wystarczy, że będzie to zwyczajowe pożegnanie się z uczniami, z podkreśleniem ich zakończenia danego etapu kształcenia. Ważne jest jednak, żeby uświadomić uczniom, że ich grupa przestaje istnieć. Należy na to zwrócić szczególną uwagę w przypadku studentów studiów licencjackich, z których część zamierza kontynuować naukę na poziomie magisterskim i w związku z tym może im się wydawać, że dana grupa nadal będzie trwać. Nie mają jednak często świadomości rezygnacji części kolegów z dalszego kształcenia na tym kierunku bądź dołączenia nowych osób, które swoje studia licencjackie odbywały gdzie indziej. 


\section{Struktura grupy}

Dynamika grupy jest silnie powiązana z jej wewnętrzną strukturą. Na początku swojego istnienia, gdy grupa znajduje się w fazie orientacji i silnie ukierunkowana jest na prowadzącego, uczestnicy nie posiadają jeszcze wyraźnie przypisanych ról. Role te powstają $w$ trakcie rozwoju grupy i uwarunkowane są zachowaniami i postawami uczestników. W fazie konfliktu, słusznie zwanej także "fazą konfliktu i zajmowania pozycji” dochodzi do tworzenia się podziałów na różne typy uczestników, mających większy lub mniejszy wpływ na dynamikę grupy i jej funkcjonowanie.

Twórcą modelu pozycji hierarchicznych w grupie jest Schindler (1957), który w wyniku obserwacji grup terapeutycznych oraz grup młodzieży zauważył charakterystyczne role, zajmowane przez uczestników w trakcie ich przebywania w grupie. Model Schindlera stosowany jest obecnie w różnych rodzajach grup oraz w pracy z zespołami. Wyróżnił on cztery podstawowe pozycje, które realizowane są przez uczestników w grupach, oznaczając je literami greckiego alfabetu:

Pozycja $\alpha$

Jest to przywódca grupy. Jego cele odpowiadają celom grupy jako całości. Alfa dostarcza pomysłów, działa. Identyfikuje się z nim większość członków grupy. Nie musi w szczególny sposób się legitymizować. Jest postrzegany jako „jeden z nas” (Schindler, 1957: 308). Grupa chętnie widzi w swoim przywódcy wojownika, walczącego z wrogiem na rzecz grupy. W zależności od sposobu działania i wyrażanych postaw, wyróżnia się trzy typy $\alpha$ :

1. Alfa narcystyczny - nie jest zbytnio skupiony na samej grupie, lecz na własnych czynach. Ważne jest dla niego, aby grupa zgadzała się na jego pomysły i aby to osiągnąć, stara się ją oczarować. Często jest osobą charyzmatyczną, umie się dobrze zaprezentować na zewnątrz, potrafi przemawiać.

2. Alfa empatyczny - dzięki niemu grupa czuje się zauważana i dowartościowana. Ten typ alfy pokazuje, że grupa jest dla niego ważna

3. Alfa waleczny - potrafi być agresywny w stosunku do pozostałych członków grupy. Dzięki takiemu zachowaniu swojego przywódcy grupa jednak czuje się silna. Identyfikując się z alfq, grupa ma poczucie, że ma kogoś, kto ją obroni przed przeciwnikami (nieakceptowanymi członkami grupy czy osobami z zewnątrz).

Pozycja $\beta$

Osoba zajmująca tę pozycję w grupie musi reprezentować wiedzę merytoryczną w zakresie zainteresowań grupy, dzięki czemu cieszy się pewnym autorytetem. Beta pełni funkcję doradczą. Swoje zdanie musi jednak - w przeciwieństwie do alfy - popierać rzeczowymi argumentami. Posiada natomiast większą 
niezależność. Nie musi identyfikować się z celami grupy. Jego powiązanie z nią odbywa się poprzez alfę. To przywódca musi go zaakceptować, żeby mógł być akceptowany przez grupę. Może jednak zdarzyć się i tak, że beta zajmie pozycję alfy, gdy uda mu się pozyskać wystarczającą ilość zwolenników w grupie.

Pozycja $\gamma$

Pozycja gamma umożliwia anonimowe uczestnictwo w grupie, zanurzenie się w jej zbiorowość. Osoby zajmujące tę pozycję stanowią „ciało” grupy, w pełni identyfikują się z jej przywódcą. Gammy reprezentują sobą działania całej grupy, takie jak np. wykonywanie pewnych, charakterystycznych dla danej grupy rytuałów.

Pozycja $\omega$

Omega jest w grupie uosobieniem wroga. Osoby będące w tej roli sprawiają wrażenie bycia poza grupą. Omega często kłóci się z alfq, przez co uruchamia agresję grupy. Posiada bądź rozwija w sobie cechy, które grupa jednoznacznie identyfikuje z atrybutami wroga. Jego funkcja w grupie jest jednak bardzo istotna. Omega może reprezentować różne postawy, dzięki czemu istnieje wiele rodzajów tych pozycji w grupie:

1. hamulec - taka osoba pracuje najwolniej, szybko rezygnuje, nie potrafi jednak wprost zrezygnować z wykonania określonego zadania,

2. sceptyk - krytycznie podchodzi do zadań, jest pełen wątpliwości,

3. rebeliant - otwarcie konfrontuje się z alfq,

4. błazen - wypowiada na głos rzeczy, których inni często nie ośmiela się powiedzieć; zabawia grupę, dzięki czemu zyskuje także pewien prestiż,

5. kozioł ofiarny - wszelka wina innych zrzucana jest właśnie na niego. Grupa całkowicie wyklucza go ze swoich poczynań.

\section{Działania nauczyciela w klasie językowej uwzględniające strukturę grupy}

Podobnie jak fazy grupy charakteryzują się dużą dynamiką, tak i wewnętrzna jej struktura może ulegać zmianom $w$ trakcie rozwoju grupy. Przywódca grupy może stać się omega, beta - alfa, a gamma - ekspertem ( $\beta$ ). W badaniach nad funkcją nauczyciela w klasie językowej (Dörney i Murphey, 2003) oraz w innych opracowaniach dotyczących roli prowadzącego (Voigt, 1993, Gellert i Nowak, 2007) pojawia się twierdzenie, że jest on przywódcą, liderem. Należy tu jednak dokonać rozróżnienia między odgórnie narzuconą funkcją prowadzenia grupy (jak to ma miejsce w przypadku klasy językowej czy pracy z zespołami i grupami) a rolą członka grupy, powstałą naturalnie w wyniku określonych cech osobowości, działań czy postaw. Przy takim rozróżnieniu nauczyciel czy trener pełni funkcję pewnego rodzaju "super-alfy" z 
uwagi na zarówno jego większą władzę nad grupą jak i odpowiedzialność za nią. Podobnie jak w przypadku omegi, klasa może przez pewien okres czasu zachowywać się w stosunku do nauczyciela jak wobec wroga, nigdy jednak nie będzie on pełnił tej roli, gdyż omega nie posiada takiej władzy, jaką ma nauczyciel czy też ewentualny, zewnętrzny przeciwnik grupy.

W pracy z klasą językową nauczyciel powinien brać pod uwagę nie tylko fazę, w jakiej jego grupa się znajduje, lecz także interakcję między uczniami, wynikającą z ich pozycji w klasie. Jest to istotnie ważne przy proponowaniu uczniom pracy w podgrupach czy w parach, lecz także przy wypowiedziach pojedynczych osób na forum klasy. Pomijanie faktu istnienia hierarchicznych pozycji w grupie może spowodować nieefektywną pracę w parach, gdy np. z powodu konfliktu między omega a resztą grupy, para, w której ów nielubiany uczestnik ma pracować, będzie wykonywała swoje zadanie najkrócej, przez co ćwiczenie tak naprawdę nie zostanie w pełni zrealizowane. Poza tym omega bywa najrzadziej wybierany przez uczestników, albo przydziela mu się role, co do których wiadomo, że zakończą się niepowodzeniem. Do przygotowywania prac domowych czy prezentacji w grupach gammy chętnie wybierają betę, z którym praca jest łatwiejsza, bo to on wnosi najwięcej do zespołu. Jednocześnie gammy bardzo chętnie pracują ze sobą w parach, gdyż znają się na tyle dobrze, że ewentualne zbieranie informacji na swój temat w obcym języku odbywa się bardzo szybko, a dalszą część czasu przeznaczoną na pracę wykorzystując na prywatne rozmowy.

Przed zaproponowaniem określonego ćwiczenia dobrze jest zatem zastanowić się nad aktualną hierarchią członków grupy, aby zaproponować taki wybór partnerów do pracy, który stworzy większe prawdopodobieństwo skutecznej pracy (np. przez propozycję wybrania osoby, z którą dotychczas się nie pracowało lub różne formy losowania czy odliczania).

\section{Podsumowanie}

Proces nauczania i nauki języka obcego zależy od wielu czynników. Niemożliwe jest jednak jednoczesne uwzględnianie wszystkich podczas pracy z uczniami w klasie językowej. Dotychczasowe opracowania niewiele uwagi poświęcały aspektom dynamiki i struktury grupy, choć wielokrotnie wymieniane są one jako istotne elementy w interakcji nauczyciel - uczeń czy uczeń - uczeń.

Podstawowe znaczenie ma uświadomienie sobie, że klasa językowa jako grupa przechodzi określone fazy swojego rozwoju i działania nauczyciela oraz odpowiedź ze strony uczniów w dużym stopniu mogą zależeć od etapu, na jakim klasa aktualnie się znajduje. Reakcje te zazwyczaj nie są związane z poziomem 
motywacji, zdolnościami ucznia czy metodą nauczania wybraną przez nauczyciela. Dynamika klasy jako grupy może także ujawniać się poprzez działania określonych osób, które mają przypisane role wewnątrz klasy - przywódca, ekspert, zwykły uczestnik czy outsider. Ich zachowanie znacząco może wpłynąć na powodzenie bądź niemożność realizacji zaplanowanych działań edukacyjnych.

Mimo świadomości, że nie jest możliwe ciągłe monitorowanie zarówno dynamiki grupy jak i jej struktury, przy równoczesnym skupieniu się na realizacji programu nauczania, wydaje się jednak istotne uwzględnienie opisanych w niniejszym opracowaniu aspektów w fazie przygotowania się do zajęć, co z pewnością ułatwi pracę z klasą.

\section{BIBLIOGRAFIA}

Allport, F. H. 1924. Social psychology. Boston: Houghton Mifflin.

Barron, M. E., Krulee, G. K. 1948. „Case study of a base skill trainig group”. Journal of Social Issues 4: 10-30.

Bion, W. R. 1961. Experience in Groups. London: Tavistock.

Bradford, L. P. 1964. „Trainer-intervention: case episodes” (w) T-group Theory and Laboratory Method (red. L. P. Bradford i K. D. Benne). New York: John Wiley \& Sons Inc.: 136-137.

Brid, C. 2008. Adult Learning in Groups. Berkshire: Open University Press.

Burrow, T. 1928. „The basis of group analysis, or the analysis of the reactions of normal and neurotic individuals". British Journal of Medical Psychology 8: 198-206.

Dörney, Z., Murphey, T. 2003. Group Dynamics in the Language Classroom. Cambridge: Cambridge University Press.

Ehrman, M. E., Dörney, Z. 1998. Interpersonal Dynamics in Second Language Education: The Visible and Invisible Classroom. Thousand Oaks, CA: Sage.

Gellert, M., Nowak, C. 2007. Teamarbeit, Teamentwicklung, Teamberatung. 3. Ausgabe. Meezen: Verlag Limmer.

Helbig, G., Götze, L., Henrici, G. i Krumm, H. J. 2001. Deutsch als Fremdsprache. Ein internationales Handbuch. Berlin: Mouton de Gruyter.

Lewin, K. 1939. „Field Theory and Experiment in Social Psychology: Concepts and Methods". American Journal of Sociology 44: 868-896.

Lewin, K. 1992. „Frontiers in Group Dynamics. Concept, Method and Reality in Social Science; Social Equilibria and Social Change" (w) Classics in Group Psychotherapy (red. K. R. MacKenzie). Nowy York: The Guilford Press: 72-87.

McDougall, W. 1921. The Group Mind. Cambridge: The University Press.

Moreno, J. L. 1953. Who shall survive? Beacon: Beacon House Inc.

Parker, S. 1958. Leadership patterns in a psychiatric ward. Human relations 11: 287-301.

Schindler, R. 1957. Grundprinzipien der Psychodynamik in der Gruppe. Psyche 11: 308-314. 
Tuckman, B. W. 1965. „Developmental Sequence in Small groups”. Psychological Bulletin 63: 384-399.

Tuckman, B. W. i Jensen, M. A. C. 1977. „Stages of Small-Group Development Revisited". Group \& Organization Management 2: 419-427.

Voigt, B. 1993. „Team und Teamentwicklung”. Organisationsentwicklung 93/3: 34-49. 